\section{UNIVERSITY TRAINING OF 25. ZOOLOGISTS}

$T$ a recent meeting in the rooms of the Zoological Society of Iond $n_{0}$ the Association of British Zoologists held diggtasion on the training of zoologists in the enjorsity, giving an opportunity to discuss the Aderess which its president, Prof. $H$. Graham Calnon, had ofivered when presiding over Section $\mathrm{b}$ of the B fol $\mathrm{h}$ Association at Brighton last Sepufinipr. A largo attendance of members pointed to the ilterest which this subject clearly has for zoologists at the present time.

The discussion was begun by Prof. D. M. S. Watson, who outlined the historical development of courses of zoology in London since they were first begun by Grant at University College in 1828 . During the second half of last century, there took place the gradual establishment of the 'type' system, largely due to the work of Huxley at the Royal School of Mines and the Normal School of Science, and to that of Ray Lankester at University College; and this has survived to the present day as the basic plan upon which courses for degrees in zoology are built. As Prof. Cannon had pointed out in his address at Brighton, there was in the nineteentwenties a general revolt against the dominating position of comparative anatomy in zoological education, and Prof. A. C. Hardy illustrated from the arrangement of courses in the Department of Zoology at Oxford how much time had now to be devoted to other parts of the subject. During the period 1943-45, 71 per cent of the lectures were allotted to a systematic treatment of the various groups of the animal kingdom, and the remaining 29 per cent to such general topics as ecology and the distribution of animals, genetics, evolution, physiology, embryology, cytology and histology. For the years 1946-48, the figures were markedly different-45 per cent only of lectures were devoted to a morphological treatment of groups ; another 45 per cent to the general topics mentioned above, while the remaining 10 per cent went to a course on the history of zoology and to discussion of research topics, a weekly debate on controversial subjects. It seems doubtful, he said, whether the treatment of groups can be profitably or desirably reduced from this, as an understanding of their anatomy and relationships is necessary for the proper treatment of the more general part of the course.

Prof. Hardy emphasized that a course on zoology such as this is essential for the training of professional zoologists : for the general education of the university student reading other subjects, he was prepared to agree with Prof. S. Mangham, who addressed the Association on the recent memorandum prepared by the Association of Scientific Workers on the teaching of biology in universities. This memorandum proposes what is, in effect, the disappearance of separate university departments and courses of botany and zoology, and their replacement by a single integrated department and course of biology, on the ground that world conditions emphasize the need for a new approach to social and food problems, and that this could be well achieved through biology. A biological training, too, would produce not only good technicians but also good citizens, and so could well become a regular part of the curriculum for arts as well as for all kinds of science degrees. So far as the content of the courses was concerned, there was suggested the same kind of distribution of emphasis as indicated by Prof. Hardy (and which later discussion showed was, in fact, general throughout the universities)-a reduction in the teaching of evolutionary morphology, the time thus gained being used to give a more generous treatment of ecology, genetics, physiology, parasitology, human biology and the history of science.

Mr. H. W. Parker, speaking on the needs of the museums, emphasized that they require educated zoologists. The fields of knowledge needed in a museum zoologist's career would appear to be essentially compatible with a good general education, and no radical changes in the present zoological courses are called for, though changes of emphasis and timing might be beneficial. For example, natural history, being ill suited to laboratory methods, receives insufficient attention, and taxonomy is out of fashion now that the pertinent question is "How does evolution take place?" rather than "Has it taken place ?" Yet, although geneticists and others may show how evolution can take place, the tax. onomist can show how it has done so, or is doing so now. Greater taxonomic training would also lead to greater appreciation of the vast range and complexity of animate Nature, a matter which the 'type' system under-emphasizes. Museums must obtain recruits with knowledge suitable for developing new lines of attack : the scant attention by taxonomists to myology, compared with osteology, Mr. Parker said, reflects the different emphases on these two subjects in the universities, and the preponderant attention to marine zoology in most courses has repercussions in the museums. For the proper understanding of the relationships of recent animals, knowledge of the environmental conditions of the immediate past is essential, and this calls for acquaintanceship with geophysics and climatology. Finally, since abiding interests develop more readily in familiar than in unfamiliar fields, Mr. Parker pressed for greater collaboration and for the encouragement of students to visit and actually work in the museums.

\section{RELATION OF A ClOVER JUICE FACTOR CAUSING PARALYSIS OF SMOOTH MUSCLE TO BLOAT IN RUMINANTS}

\author{
BY DR. W. CHARLES EVANS \\ E. T. REES EVANS
}

Department of Animal Health, University College of Wales, Aberystwyth

$\mathrm{H}^{\mathrm{ERGUSON}}{ }^{1}$ observed that whereas the juices of the most prevalent pasture grasses in Great Britain had little effect on the isolated rabbit intestine, those from certain legumes (for example, clover, lucerne) caused relaxation and paralysis. He excluded the possibility of certain inorganic ions, protein and alkaloid components from being responsible for this phenomenon. The importance of this finding in problems associated with the 'pasture-grazing animal' interrelationships is apparent. 